\title{
Young Women's Access to and Use of Contraceptives: The Role of Providers' Restrictions in Urban Senegal
}

\section{By Estelle M. Sidze, Solène Lardoux, llene S. Speizer, Cheikh M. Faye, Michael M. Mutua and Fanding Badji}

Estelle M. Sidze is associate research scientist, Cheikh M.

Faye is senior research scientist and Michael

M. Mutua is data

analyst-all with the

African Population and Health Research

Center, Nairobi,

Kenya. Solène

Lardoux is associate

professor, Department of Demography, University of

Montreal, Canada.

Ilene S. Speizer

is research profes-

sor, Department of

Maternal and Child

Health, University

of North Carolina,

Gillings School of

Global Public Health,

Chapel Hill, NC,

USA. Fanding Badji

is project coordinator,

Senegalese Urban

Reproductive Health Initiative, IntraHealth International, Dakar, Senegal.

CONTEXT: Contraceptive prevalence is very low in Senegal, particularly among young women. Greater knowledge is needed about the barriers young women face to using contraceptives, including barriers imposed by health providers.

METHODS: Survey data collected in 2011 for the evaluation of the Urban Reproductive Health Initiative in Senegal were used to examine contraceptive use, method mix, unmet need and method sources among urban women aged 15-29 who were either currently married or unmarried but sexually active. Data from a sample of family planning providers were used to examine the prevalence of contraceptive eligibility restrictions based on age and marital status, and differences in such restrictions by method, facility type and provider characteristics.

RESULTS: Modern contraceptive prevalence was $20 \%$ among young married women and $27 \%$ among young sexually active unmarried women; the levels of unmet need for contraception-mostly for spacing-were $19 \%$ and $11 \%$, respectively. Providers were most likely to set minimum age restrictions for the pill and the injectable-two of the methods most often used by young women in urban Senegal. The median minimum age for contraceptive provision was typically 18. Restrictions based on marital status were less common than those based on age.

CONCLUSIONS: Training and education programs for health providers should aim to remove unnecessary barriers to contraceptive access.

International Perspectives on Sexual and Reproductive Health, 2014, 40(4):176-183, doi: 10.1363/4017614

Family planning services were introduced in Senegal in the early 1960s at the private Blue Cross Clinic in Dakar, but it was only in 1981 that the government developed an administrative structure capable of directing a national program and began to provide information, education and counseling support and family planning services. Wider provision of family planning prior to 1981 was prohibited by a law passed during the 1920s, when Senegal was a French colony, ${ }^{1}$ and repealed only in 1980. In 1988, a national population policy was issued, giving official and political approval of the family planning program and paving the way for progress in family planning in Senegal.

But despite changes in Senegal's legal and regulatory environment in regard to family planning, contraceptive prevalence has been slow to increase. According to the 2010-2011 Senegalese Demographic and Health Survey (DHS), only $12 \%$ of currently married women used a modern contraceptive method, compared with 8\% in 1997 and $10 \%$ in $2005 .^{2}$ This slow change can be attributed to low demand for contraceptives, as well as to supply-side barriers. For instance, most African countries have been providing oral contraceptives and injectables through community-based distribution programs for decades; however, Senegal pilot-tested such a program only in 2012-2013, a delay caused by illogical restrictions on which types of providers can supply oral contraceptives and injectables. ${ }^{3}$

Nearly $30 \%$ of currently married Senegalese women have an unmet need for family planning-that is, they want to either postpone their next birth for at least two years or stop childbearing altogether, but are not currently using a contraceptive method; ${ }^{2}$ the current level is slightly lower than in 2005 (32\%). The level of unmet need in Senegal-especially for spacing (29\% among currently married women)-is higher than in other West African countries, such as Burkina Faso, Ghana, Mali and Nigeria. ${ }^{4}$

Factors contributing to unmet need for family planning in developing countries include lack of contraceptive knowledge; poor quality of and access to family planning services; method cost; women's concerns about side effects; and women's, husbands' or family members' objections to contraceptive use. ${ }^{4,5}$ According to a descriptive analysis of Urban Reproductive Health Initiative data, women's beliefs and misconceptions about contraceptives, husbands' objections to contraceptive use and the poor quality of family planning services are the most frequent reasons deterring women in urban Senegal from practicing contraception. ${ }^{6}$

Youth constitute a key target in reproductive health strategies and, in Senegal, appear to have particularly low levels of contraceptive use. For example, in 2010-2011, only $2 \%$ of all $15-19$-year-olds and $6 \%$ of all 20-24-yearolds reported using a modern method; ${ }^{2}$ the proportions among currently married women in those age-groups were slightly higher (5\% and 8\%, respectively). Access to reproductive health services remains an issue for young women 
and men because of cultural, medical and financial barriers. ${ }^{7-9}$ For example, although there are no legal restrictions to providing oral contraceptive pills to unmarried young women, results from simulated client studies suggest that providers are reluctant to do so and tend to promote abstinence instead. ${ }^{7,9}$ Consequences among young women of lack of access to reproductive health services are increased risk of unplanned pregnancy; unsafe abortion; STIs, including HIV; and early school dropout due to pregnancy. ${ }^{7}$

Previous research has stressed the importance of helping young people in developing countries to be effective contraceptive users. ${ }^{10-12}$ As the medical mediators between clients' knowledge and fears and their use of contraceptives, health providers are also key to ensuring access to, and adoption and continued use of, contraceptive methods among youth. Health providers' knowledge and training influence access to specific contraceptives. ${ }^{13,14}$ In Tanzania, Speizer et al. demonstrated examples of obstacles that prevent women from using modern contraceptives, such as inappropriate contraindications, eligibility restrictions, unnecessary process hurdles, overspecialization of providers, bias and unnecessary regulations. ${ }^{13}$

This study examines the role family planning providers' restrictions play in young women's access to and use of modern contraceptives in urban Senegal. Norms and policies have been developed over the years in Senegal to ensure that all individuals receive family planning services without any discrimination based on age, sex, marital status, ethnic group or religious affiliation. ${ }^{15-18}$ With regard to health services for young people in particular, the latest Senegalese national health development plan (20092018) specifies that health professionals should be able to counsel adolescents on pregnancy prevention, as well as on prevention of and voluntary testing for STIs. ${ }^{17}$ These responsibilities are clearly defined in training curricula for doctors, nurses, midwives and social workers, and are to be carried out without any stigmatization. Yet, very few studies have used provider data to assess the prevalence of providers' restrictions for young people. ${ }^{13,14}$ We do so here by facility type, method type, and providers' gender, age and specialization.

\section{DATA AND METHODS}

The study draws on data on women and health providers collected by the Measurement, Learning and Evaluation (MLE) project in Senegal as part of the evaluation of the Senegal Urban Reproductive Initiative, a five-year project (2010-2015) financed by the Bill \& Melinda Gates Foundation. The initiative's goal is to implement specific programs as part of a pilot project to show how using innovative approaches based on high-quality health care delivery in the public and private sectors-as well as demand creation and advocacy efforts-can significantly increase the use of modern family planning methods in urban francophone Africa. The MLE project received ethical approval from the National Ethics Committee of Senegal and the institutional review board of the University of North Caro- lina at Chapel Hill. Study participants were requested to sign a consent form and had the right to withdraw at any time, without reprisal.

\section{Survey of Women}

As part of the MLE project, a survey of women was conducted in 2011 using a two-stage stratified area sampling procedure to obtain a representative sample of women aged 15-49 in six urban sites (Dakar, Guédiawaye, Kaolack, Mbao, Mbour and Pikine). In the first stage, 32-64 primary sampling units were selected with probability proportional to population size of each site. In the second stage, a random sample of 21 households was chosen from each selected primary sampling unit, and all women aged 15-49 in those households who were identified as habitual residents or visitors were eligible for individual interviews.

Respondents answered questions about their social and demographic characteristics, marital and reproductive histories, fertility preferences, awareness and use of contraceptives, sources of contraceptives, spousal communication about contraceptive use and fertility preferences, migration history and exposure to media. Information about women's unmet need for spacing and limiting births was also collected. Women were considered to have an unmet need for spacing if they reported that their last or current pregnancy was mistimed or that they were fertile, were not practicing contraception and wanted to wait at least two years before having their next child. Women were considered to have an unmet need for limiting if they reported that their last or current pregnancy was unwanted or that they were fertile, were not practicing contraception and did not want any more children. Currently pregnant women who became pregnant while using a contraceptive method were excluded from determinations of unmet need.

Overall, 9,614 women were successfully interviewed; the response rate was $89 \% .{ }^{19}$ Sample weights were applied to adjust for the sample size at the different sites and for nonresponse. For our analyses, we selected two weighted samples of young women aged 15-29. One sample consisted of the 2,340 young women who reported being currently married; the other sample consisted of the 237 who reported having initiated sex, having been sexually active during the 12 months preceding the survey and not being married to or living with a man at the time of the survey. Descriptive analyses of young women's modern contraceptive use, method choice and method source were conducted using the svy command in Stata. Confidence intervals were calculated to show the level of difference or similarity between comparison proportions, and standard errors were adjusted for clustering. Analyses were performed separately for the two samples to account for the differences in contraceptive demand between the two groups.

\section{Health Facility Survey}

The MLE project also collected data in 2011 from health facilities that supplied reproductive health services and from providers who worked in such facilities. For the sampling 
procedure, a list of operational health facilities providing reproductive health services in survey sites was obtained from the Ministry of Health. This list was updated using information from Dakar Medical Region, Mbour Health District, Kaolack Health District, National Health Information System and IntraHealth, and included 269 health facilities. Some 205 (76\%) were successfully located and surveyed, of which 153 were public facilities (eight hospitals, 22 health centers, 111 health posts and 12 other public facilities such as dispensaries and community health centers) and 52 were private ( 27 hospitals or clinics, 10 faith-based facilities, five nongovernmental organization clinics and 10 other private providers).

For each facility, 2-4 providers involved in the provision of reproductive health services (i.e., doctors, nurses, trained midwives, maternal and child health aides, medical assistants and auxiliary staff) were randomly selected for interview from a list of active, permanent facility personnel on duty when interviewers visited. The number of providers selected depended on how many were involved in the provision of reproductive health services at the facility. A total of 637 providers were interviewed: 516 from public facilities ( 32 from hospitals, 81 from health centers, 364 from health posts and 39 from other public facilities) and 121 providers from private facilities.

All selected providers answered questions about the reproductive services offered at their facility, as well as their demographic characteristics and medical specialization. Providers were asked about the two restrictions most likely to affect young women's access to contraceptive methods: minimum age and marital status. For selected modern contraceptive methods (the pill, the injectable, the implant, condoms and emergency contraception), providers were asked, "What is the minimum age you would offer the method to anyone?" and "Would you offer this method to an unmarried person?" Providers who did not report a minimum age were considered as not restricting provision of contraceptive methods by age. Providers who reported that they would not offer a given method to an unmarried person were considered to restrict provision of that method based on marital status.

For each of the selected methods, we divided the number of providers applying minimal age and marital status restrictions by the total number of providers who reported offering the method at their facility at the time of interview. We present these estimated percentages separately for public and private health facilities; although staff at both types of facilities receive the same training and are required to follow the same national guidelines for family planning service delivery, differences in the prevalence of restrictions could be observed due to differences in monitoring systems. In addition, we computed median ages below which providers would not offer a specific method, as well as interquartile ranges-a measure of dispersion computed as the difference between the 75th percentile (Q3) and the 25th percentile (Q1).

Finally, we conducted chi-square analyses to examine the levels of minimum age and marital status restrictions by providers' gender, age and specialization. We restrict the results to the three methods found to be most commonly used by young women in urban Senegal: the pill, the injectable and condoms.

\section{RESULTS}

\section{Use and Sources of Contraceptives}

The proportion of young urban Senegalese women who reported using a modern contraceptive method was 20\% among those currently married and 27\% among those who were unmarried and sexually active (Table 1 ). The greatest proportion of the married group relied on the injectable (43\%), followed by the pill (33\%) and the condom (15\%); this pattern was consistent across age-groups. In contrast, the greatest proportion of the sexually active unmarried group relied on the condom (56\%), followed by the injectable (21\%) and the pill (14\%). Overall, 19\% of married women had an unmet need for contraception, almost all for spacing; the highest level of unmet need for spacing was among 20-24-year-olds (20\%). Among sexu-

\begin{tabular}{|c|c|c|c|c|c|c|c|c|c|c|c|}
\hline \multirow{2}{*}{$\begin{array}{l}\text { Marital status } \\
\text { and age }\end{array}$} & \multirow{2}{*}{$\begin{array}{l}\% \text { using } \\
\text { modern } \\
\text { method }\end{array}$} & \multicolumn{7}{|c|}{$\%$ distribution of users } & \multicolumn{3}{|c|}{$\%$ unmet need } \\
\hline & & Pill & Injectable & Implant & IUD & Condom & Other & Total & Spacing & Limiting & Total \\
\hline \multicolumn{12}{|c|}{ Married $(\mathrm{N}=2,340)$} \\
\hline All & $\begin{array}{l}19.7 \\
(18.0-21.6)\end{array}$ & $\begin{array}{l}32.7 \\
(28.1-37.6)\end{array}$ & $\begin{array}{l}42.5 \\
(37.6-47.5)\end{array}$ & $\begin{array}{l}6.9 \\
(4.7-10.0)\end{array}$ & $\begin{array}{l}2.3 \\
(1.3-4.1)\end{array}$ & $\begin{array}{l}15.2 \\
(11.7-19.3)\end{array}$ & $\begin{array}{l}0.5 \\
(0.1-1.4)\end{array}$ & 100.0 & $\begin{array}{l}18.9 \\
(17.2-20.8)\end{array}$ & $\begin{array}{l}0.3 \\
(0.1-0.5)\end{array}$ & $\begin{array}{l}19.2 \\
(17.5-21.1)\end{array}$ \\
\hline $20-24$ & $\begin{array}{l}21.6 \\
(18.7-24.7)\end{array}$ & $\begin{array}{l}28.6 \\
(22.1-36.1)\end{array}$ & $\begin{array}{l}44.6 \\
(37.1-52.4)\end{array}$ & $\begin{array}{l}3.8 \\
(1.9-7.4)\end{array}$ & $\begin{array}{l}2.8 \\
(1.2-6.3)\end{array}$ & $\begin{array}{l}20.3 \\
(14.2-28.1)\end{array}$ & $\begin{array}{l}0.0 \\
\text { na }\end{array}$ & 100.0 & $\begin{array}{l}20.3 \\
(17.6-23.3)\end{array}$ & $\begin{array}{l}0.2 \\
(0.1-0.5)\end{array}$ & $\begin{array}{l}20.5 \\
(17.9-23.5)\end{array}$ \\
\hline $25-29$ & $\begin{array}{l}21.7 \\
(19.1-24.5)\end{array}$ & $\begin{array}{l}36.3 \\
(29.9-43.3)\end{array}$ & $\begin{array}{l}40.9 \\
(34.2-48.0)\end{array}$ & $\begin{array}{l}9.7 \\
(6.1-15.2)\end{array}$ & $\begin{array}{l}2.2 \\
(1.0-4.8)\end{array}$ & $\begin{array}{l}10.0 \\
(6.7-14.6)\end{array}$ & $\begin{array}{l}0.9 \\
(0.3-2.7)\end{array}$ & 100.0 & $\begin{array}{l}18.8 \\
(16.3-21.7)\end{array}$ & $\begin{array}{l}0.4 \\
(0.2-0.8)\end{array}$ & $\begin{array}{l}19.2 \\
(16.6-22.0)\end{array}$ \\
\hline \multicolumn{12}{|c|}{ Unmarried ( $N=237$ ) } \\
\hline
\end{tabular}

Notes: Figures in parentheses are $95 \%$ confidence intervals. na=not applicable. 


\begin{tabular}{|c|c|c|c|c|c|}
\hline Source & $\begin{array}{l}\text { All } \\
(\mathrm{N}=536)\end{array}$ & $\begin{array}{l}\text { Pill } \\
(\mathrm{N}=166)\end{array}$ & $\begin{array}{l}\text { Injectable } \\
(\mathrm{N}=239)\end{array}$ & $\begin{array}{l}\text { Implant } \\
(\mathrm{N}=36)\end{array}$ & $\begin{array}{l}\text { Condom } \\
(\mathrm{N}=77)\end{array}$ \\
\hline Public & 66.5 & $66.1(57.3-73.9)$ & $83.8(76.0-89.4)$ & $95.4(83.3-98.9)$ & $5.2(1.8-13.7)$ \\
\hline Hospital & 2.1 & $2.3(0.8-6.2)$ & $1.5(0.6-3.8)$ & $10.4(4.4-22.5)$ & 0.0 \\
\hline Health center & 17.2 & $19.3(13.1-27.7)$ & $13.3(9.2-18.9)$ & $60.1(41.1-76.6)$ & $1.2(0.2-8.1)$ \\
\hline Health post & 42.8 & $39.3(30.9-48.4)$ & $63.7(55.9-70.9)$ & $24.1(11.8-43.0)$ & $3.7(1.0-12.5)$ \\
\hline Other publict & 4.4 & $5.2(2.3-11.2)$ & $5.3(2.9-9.6)$ & $0.8(0.1-5.8)$ & $0.2(0.0-1.7)$ \\
\hline Private & 26.1 & $29.9(22.5-38.5)$ & $14.6(9.2-22.5)$ & 0.0 & $61.1(46.7-73.8)$ \\
\hline Hospital/clinic & 8.2 & $9.1(4.9-16.2)$ & $11.3(6.4-19.3)$ & 0.0 & $1.0(0.1-6.7)$ \\
\hline Other private & 17.9 & $20.8(14.8-28.5)$ & $3.3(1.5-7.2)$ & 0.0 & $60.1(45.8-72.9)$ \\
\hline NGO/otherł & 7.4 & $4.0(1.6-9.7)$ & $1.6(0.6-4.1)$ & $4.6(1.1-16.7)$ & $33.7(21.5-48.5)$ \\
\hline Total & 100.0 & 100.0 & 100.0 & 100.0 & 100.0 \\
\hline
\end{tabular}

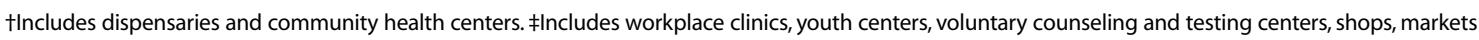
and peer educators. Notes: $\mathrm{NGO}=$ nongovernmental organization. Data for the IUD and other methods are not presented because of small sample sizes.

ally active unmarried women, the level of unmet need for contraception-all for spacing-was $11 \%$.

Sixty-seven percent of all young women currently using a modern method of contraception reported obtaining that method from the public sector (2\% from hospitals, $17 \%$ from health centers, $43 \%$ from health posts and $4 \%$ from other public health facilities; Table 2). Health posts were the facility type most commonly cited by women as their public source for the pill (39\%) and the injectable (64\%); health centers were the most common public source for the implant (60\%). Twenty-six percent of young women obtained their contraceptive method from the private sector. Young women mostly turned to privatesector health facilities for condoms (61\%); however, 34\% of condom users obtained the method from NGOs or other facilities.

\section{Minimum Age and Marital Status Restrictions}

Public-sector providers commonly apply a minimum age restriction for provision of contraceptives, including the pill and the injectable-two of the most commonly used methods among young women (Table 3). Overall, 57\% of public-sector providers reported that they would not provide a client below a certain age with the pill; that proportion was $59 \%$ in hospitals, $47 \%$ in health centers and in other public facilities, and $46 \%$ in health posts. For the injectable, $44 \%$ of public-sector providers applied a minimum age restriction; that proportion was $52 \%$ in hospitals, $43 \%$ in health centers, $40 \%$ in health posts and $37 \%$ in other public facilities. In addition, $45 \%$ of public-sector providers applied an age restriction for the implant, 25\% for the condom and $24 \%$ for emergency contraception. In private facilities, the proportion of providers who required

\begin{tabular}{|c|c|c|c|c|c|c|}
\hline \multirow[t]{2}{*}{ Barrier/method } & \multicolumn{5}{|l|}{ Public } & \multirow{2}{*}{$\begin{array}{l}\text { Private } \\
\text { All } \\
(\mathrm{N}=121)\end{array}$} \\
\hline & $\begin{array}{l}\text { All } \\
(\mathrm{N}=516)\end{array}$ & $\begin{array}{l}\text { Hospitals } \\
(\mathrm{N}=32)\end{array}$ & $\begin{array}{l}\text { Health centers } \\
(\mathrm{N}=81)\end{array}$ & $\begin{array}{l}\text { Health posts } \\
(\mathrm{N}=364)\end{array}$ & $\begin{array}{l}\text { Othert } \\
(\mathrm{N}=39)\end{array}$ & \\
\hline \multicolumn{7}{|l|}{ Minimum age } \\
\hline Pill & 57.0 & 59.3 & 47.3 & 46.0 & 46.9 & 48.8 \\
\hline Injectable & 43.6 & 51.9 & 42.5 & 40.1 & 36.7 & 41.4 \\
\hline Implant & 45.2 & 52.0 & 44.9 & 32.7 & 37.5 & 38.1 \\
\hline Condoms & 24.5 & 29.6 & 25.0 & 16.0 & 25.7 & 19.9 \\
\hline EC & 24.2 & 26.9 & 22.2 & 18.1 & 34.8 & 21.1 \\
\hline \multicolumn{7}{|c|}{ Median minimum age } \\
\hline Pill & $17(3)$ & $18(4)$ & $17(3)$ & $17(3)$ & $15(2)$ & $18(3)$ \\
\hline Injectable & $18(5)$ & $19(2)$ & $18(9)$ & $18(5)$ & $18(7)$ & $18(4)$ \\
\hline Implant & $18(7)$ & $20(7)$ & $20(7)$ & $18(9)$ & $18(2)$ & $18(4)$ \\
\hline Condoms & $18(3)$ & $18(5)$ & $17(3)$ & $18(3)$ & $18(1)$ & $18(2)$ \\
\hline $\mathrm{EC}$ & $18(3)$ & $18(5)$ & $17(5)$ & $17(3)$ & $18(2)$ & $18(3)$ \\
\hline \multicolumn{7}{|l|}{ Marital status } \\
\hline Pill & 12.2 & 12.5 & 18.5 & 9.6 & 23.1 & 20.7 \\
\hline Injectable & 13.6 & 12.5 & 18.5 & 12.1 & 17.9 & 28.1 \\
\hline Implant & 13.6 & 12.5 & 25.9 & 11.0 & 12.8 & 29.8 \\
\hline Condoms & 8.3 & 6.3 & 11.1 & 7.4 & 12.8 & 11.6 \\
\hline $\mathrm{EC}$ & 8.7 & 6.3 & 13.6 & 7.7 & 10.3 & 21.5 \\
\hline
\end{tabular}


TABLE 4. Percentage of family planning providers who apply a minimum age restriction to contraceptive provision, by providers'gender, age and type, according to health care sector and method

\begin{tabular}{|c|c|c|c|c|c|c|c|c|c|c|}
\hline \multirow[t]{2}{*}{ Characteristics } & \multicolumn{5}{|c|}{ Public } & \multicolumn{5}{|c|}{ Private } \\
\hline & $\begin{array}{l}\text { No.of } \\
\text { providers }\end{array}$ & Pill & Injectable & Condom & $\begin{array}{l}\text { Any of } \\
\text { the } 3\end{array}$ & $\begin{array}{l}\text { No.of } \\
\text { providers }\end{array}$ & Pill & Injectable & Condom & $\begin{array}{l}\text { Any of } \\
\text { the } 3\end{array}$ \\
\hline \multicolumn{11}{|l|}{ Sex } \\
\hline Male & 86 & 65.2 & $54.1^{* *}$ & 32.0 & $58.1^{*}$ & 21 & 66.7 & 63.2 & 30.0 & 66.5 \\
\hline Female & 430 & 44.0 & $38.9 * *$ & 16.4 & $44.7^{*}$ & 100 & 54.9 & 39.0 & 23.2 & 51.0 \\
\hline \multicolumn{11}{|l|}{ Age } \\
\hline$<30$ & 66 & 47.5 & 42.6 & 18.0 & 48.5 & 22 & 55.0 & 45.0 & 31.6 & 54.5 \\
\hline $30-39$ & 153 & 44.2 & 41.2 & 21.0 & 48.4 & 40 & 52.9 & 38.2 & 23.5 & 52.5 \\
\hline$\geq 40$ & 297 & 48.5 & 40.5 & 18.0 & 45.8 & 59 & 60.9 & 46.8 & 22.4 & 54.2 \\
\hline \multicolumn{11}{|l|}{ Provider type } \\
\hline Doctor & 13 & $33.3^{* *}$ & 45.5 & 33.3 & $38.5^{* *}$ & 19 & 52.9 & 44.4 & 16.7 & 57.9 \\
\hline Nurse & 131 & $62.0^{* *}$ & 51.9 & 31.0 & $57.3^{* *}$ & 25 & 70.6 & 52.9 & 40.0 & 60.0 \\
\hline Midwife/other & 372 & $42.8^{* *}$ & 37.5 & 14.2 & $43.5^{* *}$ & 77 & 54.5 & 40.9 & 21.9 & 50.6 \\
\hline
\end{tabular}

clients to be above a certain age to receive a contraceptive method was $49 \%$ for the pill, $41 \%$ for the injectable, $38 \%$ for the implant, $20 \%$ for the condom and $21 \%$ for emergency contraception.

Overall, the median minimum age required by public providers who reported having an age restriction for contraceptives was 17 for the pill and 18 for the injectable, the implant, the condom and emergency contraception; the median minimum age was as high as 20 for provision of the implant in public hospitals and health centers. In the private sector, the median minimum age was 18 for all methods studied.

In general, restrictions on contraceptive provision because of marital status were less common than those because of age. Overall, 12-14\% of providers in public health facilities reported requiring that a woman be married to receive the pill, the injectable or the implant, and 8-9\% applied a marital status restriction for condoms and emergency contraception. In private health facilities, $21-30 \%$ of providers reported refusing to offer unmarried women the pill, the injectable, the implant or emergency contraception; $12 \%$ imposed a marital status restriction for condoms.

\section{Restrictions by Providers' Characteristics}

Contraceptive restrictions varied among providers depending on their characteristics. For instance, among public-sector providers, a greater proportion of men than of women reported applying a minimum age restriction for provision of the injectable (54\% vs. 39\%; Table 4); male providers at public facilities were also more likely than their female peers to restrict young clients' access to at least one of the three methods studied (58\% vs. $45 \%$ ). In the private sector, male providers were generally more likely than female providers to apply minimum age restrictions to contraceptive method provision, although no significant differences by gender were found. It is important to note that few public- or private-sector providers of the pill, the injectable or condoms were male.

The proportion of public and private providers who reported applying minimum age restrictions to contracep-

\begin{tabular}{|c|c|c|c|c|c|c|c|c|c|c|}
\hline \multirow[t]{2}{*}{ Characteristics } & \multicolumn{5}{|c|}{ Public } & \multicolumn{5}{|c|}{ Private } \\
\hline & $\begin{array}{l}\text { No.of } \\
\text { providers }\end{array}$ & Pill & Injectable & Condom & $\begin{array}{l}\text { Any of } \\
\text { the } 3\end{array}$ & $\begin{array}{l}\text { No.of } \\
\text { providers }\end{array}$ & Pill & Injectable & Condom & $\begin{array}{l}\text { Any of } \\
\text { the } 3\end{array}$ \\
\hline \multicolumn{11}{|l|}{ Sex } \\
\hline Male & 86 & 9.3 & 9.3 & 8.1 & 12.8 & 21 & 19.0 & 14.3 & 14.3 & 19.0 \\
\hline Female & 430 & 12.8 & 14.4 & 8.4 & 18.1 & 100 & 21.0 & 31.0 & 11.0 & 36.0 \\
\hline \multicolumn{11}{|l|}{ Age } \\
\hline$<30$ & 66 & $4.5^{*}$ & 6.1 & 6.1 & 7.6 & 22 & 31.8 & 40.9 & 9.1 & 45.5 \\
\hline $30-39$ & 153 & $9.2^{*}$ & 11.8 & 5.9 & 17.0 & 40 & 20.0 & 35.0 & 10.0 & 37.5 \\
\hline$\geq 40$ & 297 & $15.5^{*}$ & 16.2 & 10.1 & 19.5 & 59 & 16.9 & 18.6 & 13.6 & 25.4 \\
\hline \multicolumn{11}{|l|}{ Provider type } \\
\hline Doctor & 13 & 7.7 & 7.7 & 7.7 & 7.7 & 19 & 21.1 & 15.8 & 15.7 & 21.1 \\
\hline Nurse & 131 & 14.5 & 13.9 & 9.2 & 17.5 & 25 & 28.0 & 28.0 & 16.0 & 32.0 \\
\hline Midwife/other & 372 & 1.6 & 13.7 & 8.1 & 17.7 & 77 & 18.2 & 31.2 & 9.1 & 36.4 \\
\hline
\end{tabular}


tive method provision were generally consistent across provider age-groups. In regard to provider type, in the public sector, greater proportions of nurses than of other providers reported having a minimum age restriction for the pill (62\% vs. $33-43 \%)$ or for at least one of the three methods ( $57 \%$ vs. $39-44 \%$ ); the pattern by provider type in the private sector seemed to follow that seen in the public sector, but no differences were significant.

In our analyses of providers' restrictions based on marital status, we found only one significant finding: the proportion of public staff who would not provide the pill to unmarried women increased with provider's age (from 5\% among those younger than 30 to 9\% among those 30-39 and $16 \%$ among those 40 or older; Table 5, page 180). The pattern by age seemed to also apply to provision of the injectable and condoms at public facilities, but was opposite for pill and injectable provision at private facilities; however, the differences were not significant. In general, female providers were slightly more likely than male providers to require clients to be married to receive contraceptives; female providers in private facilities were generally more restrictive than their counterparts in public facilities. In regard to provider type, in the public sector, restrictions by marital status generally were more common among nurses than among other providers; in the private sector, midwives appeared to be the provider type most likely to restrict unmarried women's access to contraceptives.

Further analyses (not shown) indicated no correlation between minimum age restrictions and parity restrictions.

\section{DISCUSSION}

As unmet need remains high in Senegal, 2,4 family planning programs face challenges in removing barriers to family planning access and use. Young people have particularly low levels of contraceptive use, despite being knowledgeable of contraceptive methods. ${ }^{3}$ In this study, we found that in urban Senegal, only about one-fifth of married young women and one-fourth of unmarried, sexually active young women reported current use of a modern contraceptive method. In addition, one in five married young women and one in 10 unmarried, sexually active young women had an unmet need for contraception. These levels of contraceptive use and unmet need suggest a need for improvement in family planning services for youth in urban Senegal.

An important goal of this study was to investigate the role providers' restrictions play in young women's access to contraceptives. Providers are key to ensuring young people's access to, and adoption and continued use of, contraceptive methods; thus, provider biases and restrictions may hamper young people's access and use.

According to our findings, providers in Senegal seem generally more likely to impose restrictions based on age than on marital status; this pattern has been reported in previous research. ${ }^{14}$ More than half of providers in the public sector and almost half of those in the private sector reported applying a minimum age for provision of the pill.
Minimum age restrictions for the pill and the injectable are particularly troubling, because these are the two methods most used by young married women. Minimum age restrictions for emergency contraception and the condom were relatively less common in both the private and the public sectors; however, restricting young women's access to these methods is still problematic. Emergency contraception is an effective way of preventing unwanted pregnancies among young women after unprotected sex, and the condom-the method used by the greatest proportion of unmarried, sexually active young women-is the only method that prevents against STIs (including HIV) as well as pregnancy.

On average, providers in both the public and the private sectors required clients to be at least 18 for most of the contraceptive methods studied, which presents a major barrier to contraceptive access not only for young adolescents, but for most teenagers and some young adults as well. It does not appear that providers consider parity when making decisions to restrict methods by minimum age.

We found that male providers-particularly in the public sector-were more likely than female providers to impose restrictions by minimum age for the pill, the injectable and condoms. Also in the public sector, nurses were more likely than other staff to impose minimum age restrictions for those methods. The context must be considered, however, when interpreting these results: In Senegal, few public providers of these methods are male, and different types of providers play different roles in service provision.

Previous studies have demonstrated that provider restrictions reflect the social norms and values of providers. $^{20-22}$ For example, according to Batieno, the choice of methods providers offer their female patients may perpetuate norms and values of the society. ${ }^{21}$ In Senegal, provider-imposed restrictions are most likely a reflection of the country's long history of restrictive family planning practices and a generally socially conservative environment. ${ }^{1,3}$ Strong norms exist against premarital sexuality, especially for women, and health providers may tend to promote abstinence for young women, while restricting unmarried women's access to the pill. ${ }^{9}$ Providers may also be reluctant to offer contraceptives (including condoms) to young people out of fear that youth might be stigmatized by parents or other community members.

In the provision of family planning services, concerns defined by the state of medical knowledge and scientific advances should prevail over social norms. According to the World Health Organization's report on medical eligibility criteria, even the medical concerns expressed regarding the use of certain methods must be balanced against the advantages of avoiding unintended pregnancies, particularly when it comes to youth. ${ }^{23}$ Clients' approach to choosing a contraceptive may vary according to individual social issues, such as frequency of intercourse among young adults, for example, as well as the economic activities and educational aspirations of women. In the absence of a clear regulatory framework for service provision to young peo- 
ple, health providers may refer to their own perspectives to determine how and when to offer youth services and methods. Proper provider training is essential to prevent providers from limiting the options available for young women. In addition, family planning programs should organize more regular follow-up and updates on contraception via forums and seminars for providers. Health providers currently may not have enough knowledge about methods, or about the potential health consequences and side effects of contraceptives. In Kenya and Ethiopia, for instance, counseling on and provision of emergency contraception was positively associated with providers' greater level of knowledge of the method. ${ }^{24}$ Thus, an increase in provider knowledge may allow clients better contraceptive access.

\section{Limitations}

We must acknowledge our study's limitations. Data on providers' characteristics were limited; thus, multivariate analyses examining associations between providers' characteristics and age or marital restrictions were not possible. Because only 2-4 providers were interviewed per health facility, the data may not represent all providers at the facility level; nonetheless, we believe that the data collection procedure was suitable for our study given that all facilities located in study sites were eligible for inclusion, rather than a random sample-often used in situation analyses. ${ }^{25}$ Reported age-heaping occurred in our data on the service provider minimum age restriction, particularly at age 18 and at all ages with "0" and "5" digits beyond 15 years of age; this would speak to the quality of data on age restrictions reported by service providers. Finally, the women's survey data about reasons for nonuse (among women not using contraceptives) does not fully capture the extent to which providers' restrictions could have accounted for the nonuse.

\section{CONCLUSIONS}

Findings from this study suggest several programmatic recommendations. First, training and education programs for medical staff in Senegal should aim to reduce unnecessary provider-implemented barriers to contraceptive access, such as restrictions by age or marital status. All staff of both public and private facilities should receive training and education; however, targeted training for male providers, nurses and older staff may be warranted, given evidence that those groups may be more likely to apply restrictions by age and marital status. Such programs could contribute to increased access to and use of contraceptives among young women, lower unmet need and improved health outcomes in urban Senegal and beyond.

Second, all family planning service delivery protocols or policies should make clear that young people are eligible for services. Currently, the documents related to the norms and protocols in Senegal specify no regulatory restrictions against youth's access to family planning services; however, they also do not include a clear official statement that adolescents and young people should have unrestricted access. In the absence of a clear message, providers in Senegal can define their restriction criteria based on their own opinions and values regarding sexuality and contraception.

\section{REFERENCES}

1. Wilson E, Reproductive Health Case Study, Senegal, Washington, DC: Futures Group International, 1998, <http://www.policyproject.com/ pubs/countryreports/sendbl.pdf>, accessed Aug. 21, 2013.

2. Agence Nationale de la Statistique et de la Démographie (ANSD) Sénégal and ICF International, Enquête Démographique et de Santé à Indicateurs Multiples au Sénégal (EDS-MICS) 2010-2011, Calverton, MD, USA: ANSD and ICF International, 2012.

3. FHI 360, Senegal: Community Health Workers Successfully Provide Intramuscular Injectable Contraception, Dakar, 2013, <http://www. fhi360.org/sites/default/files/media/documents/community-healthworkers-intramuscular-depo-senegal.pdf>, accessed July 8, 2014.

4. Sedgh $G$ et al., Women with an unmet need for contraception in developing countries and their reasons for not using a method, Occasional Report, New York: Guttmacher Institute, 2007, No. 37

5. Cleland J et al., Family planning: the unfinished agenda, Lancet, 2006, 368(9549):1810-1827.

6. Measurement, Learning and Evaluation (MLE) Project, 2011 Baseline Survey for the Senegal Urban Health Initiative (ISSU) Service Delivery Site Survey: Final Report, Chapel Hill, NC, USA: IntraHealth International, 2012, <http://www.urbanreproductivehealth.org/sites/mle/files/issu_ service_delivery_site_baseline_survey_english.pdf>, accessed May 12, 2013.

7. Katz K and Naré C, Reproductive health knowledge and use of services among young adults in Dakar, Senegal, Journal of Biosocial Science, 2002, 34(2):215-231

8. International Youth Foundation (IYF), Youth Map Senegal, Youth Assessment: The Road Ahead, Vol. 1: Main Report, Baltimore, MD, USA IYF, 2011, <http://www.iyfnet.org/sites/default/files/YouthMap_ Senegal_Vol.1_Report.pdf>, accessed May 12, 2013.

9. Naré C, Katz K and Tolley E, Adolescents' access to reproductive health and family planning services in Dakar (Senegal), African Journal of Reproductive Health, 1997, 1(2):15-25.

10. Blanc AK et al., Patterns and trends in adolescents' contraceptive use and discontinuation in developing countries and comparisons with adult women, International Perspectives on Sexual and Reproductive Health, 2009, 35(2):63-71

11. Biddlecom AE et al., Adolescents' views of and preferences for sexual and reproductive health services in Burkina Faso, Ghana, Malawi and Uganda, African Journal of Reproductive Health, 2007, 11(3):99-110.

12. Bankole A et al., Knowledge of correct condom use and consistency of use among adolescents in four countries in Sub-Saharan Africa, African Journal of Reproductive Health, 2007, 11(3):197-220.

13. Speizer IS et al., Do service providers in Tanzania unnecessarily restrict clients' access to contraceptive methods? International Family Planning Perspectives, 2000, 26(1):13-20 \& 42.

14. Miller $\mathrm{K}$ et al., How providers restrict access to family planning methods: results from five African countries, in: Miller K et al., eds. Clinic-Based Family Planning and Reproductive Health Services in Africa: Findings from Situation Analysis Studies, New York: Population Council, 1998, pp. 159-180.

15. Republic of Senegal, loi no. 2005-18, relative à la santé de la reproduction, Aug. 5, 2005, Chapter IV, Article 10.

16. Republic of Senegal, Politiques et Normes de Services de SR, Sénégal, Dakar, Senegal: Division de la Santé de la Reproduction, 2007.

17. Republic of Senegal, Plan National du Développement Sanitaire du Sénégal (PNDS 2009-2018), Dakar, Senegal: Ministère de la Santé et de la Prévention, 2009.

18. Republic of Senegal, Plan d'Action National de Planification Familiale 2012-2015, Dakar, Senegal: Division de la Santé de la Reproduction, 2012 
19. Measurement, Learning and Evaluation (MLE) Project, 2011 Baseline Survey for the Senegal Urban Health Initiative (ISSU) Household Survey: Final Report, 2012, <https://www.urbanreproductivehealth. org/sites/mle/files/Final_Household_Baseline_Report_ISSU_ April\%2026\%202012\%20F.pdf>, accessed Dec. 15, 2013.

20. Quesnel A and Samuel O, Mexico: Women between husband and doctor, Histoires de Développement, 1993, <http://horizon.documentation.ird.fr/exl-doc/pleins_textes/pleins_textes_6/b_fdi_33-34/38840. pdf>, accessed Nov. 23, 2012 (in French).

21. Bationo BF, The relationship between health workers and young girls in Burkina Faso, Agora Débats/Jeunesses, 2012, <www.cairn.info/ revue-agora-debats-jeunesses-2012-2-page-21.htm>, accessed Nov. 23 2012 (in French)

22. Stanback J and Twum-Baah K, Why do family planning providers restrict access to services? An examination in Ghana, International Family Planning Perspectives, 2001, 27(1):37-41.

23. World Health Organization (WHO), Medical Eligibility Criteria for Contraceptive Use, fourth ed., Geneva: WHO, 2009, <http:// www.who.int/reproductivehealth/publications/family_planning/9789241563888/en/index.html>, accessed Nov 23, 2012.

24. Judge S, Peterman A and Keesbury J, Provider determinants of emergency contraceptive counseling and provision in Kenya and Ethiopia, Contraception, 2011, 83(5):486-490.

25. Miller R et al., The Situation Analysis Approach to Assessing Family Planning and Reproductive Health Services: A Handbook, New York: Population Council, 1997.

\section{RESUMEN}

Contexto: La prevalencia del uso de anticonceptivos es muy baja en Senegal, particularmente entre las mujeres jóvenes. Es necesario un mayor conocimiento sobre las barreras que enfrentan las mujeres jóvenes para usar anticonceptivos, incluidas las barreras impuestas por los proveedores de servicios de salud.

Métodos: Se usaron datos de encuesta provenientes de la evaluación de la Iniciativa de Salud Reproductiva Urbana en Senegal para examinar el uso de anticonceptivos, tipos de métodos utilizados, necesidad insatisfecha y fuentes para la obtención de métodos entre mujeres urbanas en edades de 15 a 29 años que, en ese momento, estaban casadas o eran solteras pero sexualmente activas. Se utilizaron datos de una muestra de proveedores de servicios de planificación familiar para examinar la prevalencia de las restricciones relacionadas con la elegibilidad de anticoncepción en base a la edad y el estado conyugal, así como las diferencias en tales restricciones por método, tipo de institución de salud y características de los proveedores de servicios.

Resultados: La prevalencia del uso de anticonceptivos modernos fue de $20 \%$ entre las mujeres jóvenes casadas y $27 \%$ entre las mujeres jóvenes solteras y sexualmente activas; los niveles de necesidad insatisfecha de anticoncepción-principalmente relacionados al espaciamiento-fueron de 19\% y 11\% respectivamente. Los proveedores tuvieron una mayor probabilidad de establecer restricciones de edad mínima para la píldora y el inyectable, dos de los métodos más frecuentemente usados por mujeres jóvenes en las zonas urbanas de Senegal.
La edad mediana mínima para la provisión de anticonceptivos fue típicamente 18 años. Las restricciones basadas en el estado conyugal fueron menos comunes que aquellas basadas en la edad.

Conclusiones: Los programas de capacitación y educación dirigidos a los proveedores de salud deben procurar la eliminación de barreras innecesarias relacionadas con el acceso a los anticonceptivos.

\section{RÉSUMÉ}

Contexte: La prévalence contraceptive est très faible au Sénégal, chez les femmes jeunes en particulier. Il convient de mieux cerner les obstacles à la contraception auxquelles les jeunes femmes se trouvent confrontées, y compris ceux imposés par les prestataires de santé.

Méthodes: Les données d'enquête issues de l'évaluation de l'Initiative pour la santé reproductive en milieu urbain au Sénégal ont servi à l'examen de la pratique contraceptive, de l'éventail de méthodes, du besoin non satisfait et des sources de méthodes parmi les femmes urbaines âgées de 15 à 29 ans mariées ou non mariées mais sexuellement actives. Les données d'un échantillon de prestataires de la planification familiale ont été considérées pour l'examen de la prévalence des restrictions d'admissibilité à la contraception en fonction de l'âge et de l'état matrimonial, ainsi que des différences de restrictions en fonction de la méthode, du type d'établissement et des caractéristiques du prestataire.

Résultats: La prévalence contraceptive moderne était de 20\% parmi les jeunes femmes mariées et de $27 \%$ parmi celles non mariées mais sexuellement actives. Les niveaux des besoins non satisfaits en matière de contraception-à des fins d'espacement principalement-étaient respectivement de 19\% et 11\%. Les prestataires étaient le plus susceptibles d'imposer des restrictions d'âge minimum concernant la pilule et l'injectable, deux des méthodes les plus pratiquées par les jeunes femmes du Sénégal urbain. L'âge minimum médian pour l’obtention de la contraception était généralement de 18 ans. Les restrictions basées sur l'état matrimonial étaient moins courantes que celles imposées en fonction de l'âge.

Conclusions: Les programmes de formation et d'éducation à l'intention des prestataires de santé doivent chercher à lever les obstacles inutiles à l'accès à la contraception.

\section{Acknowledgments}

The authors gratefully acknowledge support from the Bill $E$ Melinda Gates Foundation for the support of the Urban Reproductive Health Initiative (URHI) in the target countries, as well as for the support of the Measurement, Learning and Evaluation project, the evaluation component of the URHI. Analysis time for the lead author was funded by the Gates Foundation under the Measurement, Learning and Evaluation project (grant 52037).

Author contact: esidze@aphrc.org 